Trivent Publishing

(C) The Authors, 2016

Available online at http://trivent-publishing.eu/

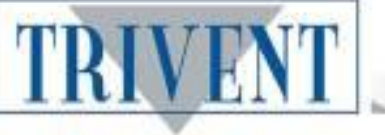

Philosophy, Communication, Media Sciences Series

Volume The Modern and Contemporary Reception of Saint Gerard of Cenad

\title{
Glossary for a Future Translation of Deliberatio supra hymnum trium puerorum
}

\author{
Radu Cernătescu
}

The Writers' Union of Romania, Romania, radu.cernatescu@ yahoo.com

\begin{abstract}
Bishop Batthyány was the first editor of Saint Gerard's treatise. His edition of Deliberatio contains a few erroneous explanations in the footnotes which risk distorting the meaning of the text. In this short essay we intend to correct some of these errors and to prepare Deliberatio supra Hymnum trium puerorum (Albo-Carolinae, 1790) for a future translation.
\end{abstract}

\section{Keywords:}

Saint Gerard of Cenad; translation difficulties; circulosum; Aristotle's theory of the syllogism; rhetoric tradition; philological clues; saliunca; ha-Naatzutz; medieval herbs; Bishop Batthyány.

This is an Open Access article distributed in accordance with the Creative Commons Attribution Non Commercial (CC-BY-NCND 4.0) license, which permits others to copy or share the article, provided original work is properly cited and that this is not done for commercial purposes. Users may not remix, transform, or build upon the material and may not distribute the modified material (http://creativecommons.org/licenses/by-nc/4.0/)

DOI: 10.22618/TP.PCMS.20163.61006 


\section{1. "quemadmodum potentes in theoricis aiunt: Nec vero declinandum, quamlibet circulosum"1}

In this phrase, Bishop Batthyány translates the ambiguous lexeme circulosum $^{2}-$ circulosam $^{3}$ as in the following: "Circulosum: id est: tortuosum [tortuous, sinuous], implexum [tangled]." ${ }^{4}$ Unfortunately, these synonyms allow the loss of precious connotations which logica vetus had provided to the Latin word circulosum. This syntagma is used by Gerard as a scholarly reference to the logical error known as circulus in probando (proving in circles, using a conclusion as the premise in an argument) or erorem circularem (the circular error) which defined for Aristotle a syllogism which uses the conclusion as a premise for the demonstration itself. This is, in fact, the origin of the expression "vicious circle" (circulosum vitiosum), which defines, in rhetoric, the error of not having an equilibrium in demonstration.

This error (dicimus circulum seu erorem circularem) is discussed by Aristotle in his treatise on Logics, translated by Boethius as Analytica priora seu resolutoria (II, 57b, $18-59 \mathrm{~b}, 1$ ). Boethius re-opens the discussion on the "circular error" of Logics is his De syllogismo categorico - a treatise which was circulated until the time of Abelard as an exemplification of the logica vetus. However, Boethius does not forget to remind the reader that "this thing is useful in presenting circular syllogisms, which are discussed in [Aristotle's] Analyticis." 5

The usage of the term ciculosum demonstrates that Gerard had studied curricula liberale - or the art of discourse (artes sermocinales) which defined the trivium and which made Ancient Logics an important part of the training of the medieval man. Preserving this connotation, we have is an important argument for the fact that Gerard was one of those dialecticians seduced by logica vetus and that he was (in terms of mentality and training) on the side of the "great theoreticians" (potentes in theoricis) to whom Gerard suggestively refers (not only in this phrase, but also in Chapter II of Deliberatio where he reminds the "liberal" Isingrim of "your theoreticians" - tuus theoricis). There is therefore no reference to the "masters of contemplation (sic)," as Batthyány translated the syntagma potentes in theoricis, which is yet another erroneous translation of the bishop.

The logical concept of "circular error" was highly used in the liberal arts. Thus the concept was also included in Alcuinus' rhetoric manual De rethorica et virtutibus where, in the post-Carolingian time, it defined the "circular and indirect argumentation" (circuitionem) and its antonym, the "clear, direct argumentation" (perspicue). Furthermore, the teacher recommended that the rhetor used "sometimes clear argumentation, other times indirect argumentation" (Aliquando perspicue, aliquando per circuitionem). ${ }^{7}$ The idea of "circularity" as synonym to difficult, tangled argumentation is kept up until today when we see it represented in rhetoric by the circumlocution (Fr., circonlocution), meaning the periphrastic substitution of one word with an expression.

By translating "quemadmodum potentes in theoricis aiunt: Nec vero declinandum, quamlibet circulosum" with "like the great theoreticians say: one must not give up, no matter how much one has to move in circles," the medieval understanding of the circular syllogism in Aristotelian theory is better kept. Furthermore, this translation may also show in a better way (maybe in a footnote) that Gerard had knowledge of logica vetus, just like the great medieval thinkers such as Boethius, Alcuinus (De rethorica), Abbo Floriacensis (Syllogismorum categoricorum et hypotheticorum enodatio), Garlandus Compotista (Dialectica), up until Abelard's Dialectica - who all kept Aristotle's theory of the syllogism alive.

\footnotetext{
${ }^{1}$ Sancti Gerardi Episcopi Chanadiensis Scripta et acta hactenus inedita, cum Serie Episcoporvm Chanadiensivm, Opera, et studio Ignatii Comitis de Batthyan, Episcopi Transylvaniae, Albo-Carolinae (Typis Episcopalibus, 1790), 1-2: "but as the great theologians say: one must not give up, regardless of how much one has to circle around." (henceforth: Batthyány).

${ }^{2}$ Ibidem, 2.

${ }^{3}$ Ibidem, 64.

${ }_{5}^{4}$ Ibidem, 2, footnote 1.

5 "Hoc tamen prodest ad ostensionem syllogismorum quae fit in circulo, quam in Analyticis diximus," Boethius, $D e$ syllogismo categorico, II [811D], in MPL 64, col. 812a.

${ }^{6}$ Batthyány, 24, footnote a.

${ }^{7}$ Alcuinus, De rethorica et virtutibus, 21, in MPL 101, col. 930d.
} 
As far as the phrase Nec vero declinandum, quamlibet circulosum is concerned, it should be highlighted that it needs no quotation marks as it should be considered a personal thought of Saint Gerard, but which makes reference to an entire rhetorical tradition.

\section{2. "De istis pomis in canticis Ecclesia fatetur: Omnia poma nova, et vetera reservavi fratrueli meo",}

First of all, canticis is in its plural form here (in Ablative) and does not refer to the singular canticum from Canticum Canticorum Salomonis, as the editor Batthyány suggests. ${ }^{9}$ In our opinion, canticis does not make reference to the Song of Solomon here, but to the medieval set of church songs known as Canticis temporale et sanctorale, un antiphonarium which was spread in the (post)Carolingian times as a liturgical calendar, summing occasional Gregorian songs and hymns. Such a collection of hymnica pro Angelorum chorum which can be found in Ms. 40047 from the State Library in Berlin, a manuscript originating ${ }^{10}$ in the beginning of the eleventh century from the Quedlinburg Abbey. On Folio 102v of this manuscript one can find the antiphon Omnia poma nova et vetera (which is also the first line of the song), with the indication that it should be sang with the choir on the feast of the Nativity of the Virgin Mary, on September $8^{\text {th }}$.

Secondly, the verse which Batthyány presumed was integrally from the Song of Songs 7:13 ("Both the new and old fruits, I have saved up for my little brother") would lead to the conclusion that Gerard was not fully acquainted with the Sacra Scriptura (!). The verse 7:13 from the Song of Songs reading, in fact, in the vulgata editio as following: "omnia poma, nova et vetera dilecte mi servavi tibi," (Both new and old fruits, I have saved up for you)."

The reference to the antiphon dedicated to the Virgin Mary in Chapter II of Deliberatio can be an important clue for dating this chapter. Its writing should be placed around the date of September $8^{\text {th }}$ (1044), an important date in the calendar of a community which had just decreed Hungary as a Kingdom of the Holy Virgin (Regnum Marianum). This is the day in which the liturgical calendar of Quedlinburg (eleventh century) recommended ${ }^{11}$ that the hymns dedicated to the Virgin Mary be sung among them also the one which refers to the "fruits" of the New and the Old Testament, to which the verse "poma nova et vetera" of the Song of Songs symbolically makes reference.

It should be highlighted that the biblical syntagma "poma nova et vetera" reappears in the last paragraph of Gerard's treatise, where, in fact, the entire verse of the Song of Songs appears: "Omnia poma nova, et vetera dilecte servavi tibi." 12 Its appearance may indicate that Gerard knew the Sacra Scriptura and that he came to prepare the Feast of the Nativity of the Virgin in another year, maybe in the year of his martyrdom, around September $24^{\text {th }} 1046$. This supports the idea (already known by exegets) that Deliberatio remained unfinished at Chapter 8 , and that Gerard wrote up until very close to the date of his death.

For future translations of the phrase "De istis pomis in canticis Ecclesia fatetur: Omnia poma nova, et vetera reservavi fratrueli meo," I recommend the following translations: "The Church talks about these fruits: in all new and old fruits, from the Songs, which I dedicate to my little brother." In this construction, fratrueli hints to Isingrim, a younger Benedictine monk, but also to "the friends who make me hear your voice" from the Biblical text, with reference to the friends of the Virgin who "lives in the garden." 13 It should be noted however that reservavi ( $1^{\text {st }}$ person singular, indicative) is not servavi (I keep) from the Biblical text, but "I dedicated," indicating here that Gerard dedicates to his younger brother and friend Isingrim the song of the antiphon which he was in the process of preparing for the Episcopal liturgy of the

\footnotetext{
${ }^{8}$ Batthyány, 26: "The Church talks about these fruits in All the New and Old Fruits, from the Songs, which I dedicate to my little brother."

${ }^{9}$ Ibidem, footnote a.

${ }^{10}$ On the dating, see: H. Möller, Das Quedlinburger Antiphonar..., vol. I (Tutzing, 1990), 32-38.

${ }^{11}$ See also: idem, vol. III, folio 101r-103v.

${ }^{12}$ Batthyány, 297.

${ }^{13}$ C.C., 8,13
} 
Holy Saturday. It should also be highlighted that this cantum had been recently introduced to the twelfthcentury antiphonarium ophicii and it did not exist in the song codex of the tenth-century Saint Gallen.

This is how the dates of September $8^{\text {th }} 1044$ and September $8^{\text {th }} 1046$ (highlighted in the annual hymnology) become benchmarks for dating the treatise of Saint Gerard. Consequently, this is also the reason for highlighting the importance of the translation of this phrase, which does not belong to the Song of Songs but to the codex of hymns with fixed days to be sung.

\section{3. „Non ignoro linguam frequenter reverberatam theologorum, atque maxima necessitate pro rosis in eloquiis ignitis Dei uti saliuncis, quemadmodum in contemplationibus iudicii mundi valde astrictus perhibetur, ubi partem vasorum Dei leniter affatim tetigit"14}

The difficulty in this phrase is given by "saliuncis/saliunca," and antique glosseme which represents, until today, a large question mark for philologists. Herba saulica appear in all modern botanical dictionaries as "Nardus celtica," with its definition taken from Theatrum botanicum, ${ }^{15}$ or Dictionarium botanicum. ${ }^{16}$ However, in Gerard's text, herba saulica has a completely different meaning, thus not referring to the herb known as valerian (as herba saulica appears translated in the philological dictionaries, including the LatinFrench one, Gaffiot, 1934). But before understating the meaning of the medieval term saulica, the history of this lexeme should be revealed. Just like Bishop Batthyány also shows, saulica is mentioned by Pliny the Elder in his Historia Naturalis, XXI, 7, as a fragrant plant which was "rather a herb than a flower" (herba verius quam flos). It should be highlighted here that Batthyány distorts a bit Pliny's classification writing that saulica was "rather a herb than a tree" (herba potius, quam arbor). ${ }^{17}$ It should also be noted that Pliny wrote that the plant mostly grew in Pannonia, a detail which makes the editor Batthyány say, filled with pride, that this is "proof that Saint Gerard wrote his book in Hungary, in the areas of Cenad, where the saulica abounds."

However, the one who assimilated the saulica with the valerian was Dioscorides (De materia medica,

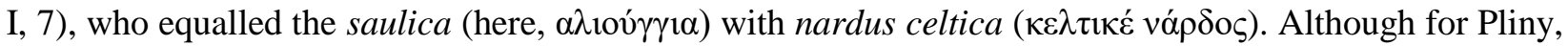
saulica was used as a natural perfume for clothes, Dioscorides believed that his aliungia was a remedy for nausea - thus a large question mark was placed between the similarities of the two.

Everything becomes more complicated with Virgil. In his Bucolicon liber, V, 17, he equalled the "humble saulica" (humilis saulica), with the "garden with red roses" (Puniceis rosetis - where rosetum is in fact "garden of roses," not simply a "rose"): "... as far as the humble saulica is from the garden of red (Carthaginian) roses..." It is interesting that Gerard kept this comparative context between the saulica and the rose, highlighted in his case by the conjunction atque, which usually introduces a comparison. However, the passage in Gerard's text cannot be a direct link to Virgil - it is rather a locus communis of the medieval paremiology, which fixed the Virgilian comparison between the humble saulica and the wondrous garden of red roses (Puniceis rosetis).

In any case, this is where the medieval understanding of the Latin saulica should be found. In the monastic environment, the lexeme used to mean "torn," directly referring to Isaiah 55:13, the verse which Saint Jerome translated as "Instead of the thorn bush (saulica), the cypress will come up, and instead of the nettle (urtica), the myrtle will come up" (Pro saliunca ascendet abies et pro urtica crescet myrtus). By equalling the Hebrew ha-Naatzutz with the Latin saulica, Saint Jerome clarified the meaning of the word as "thorn, briar." This was the plant which allowed the glossers of Isaiah to make the comparison between the unfaithful man with a land covered in thorn bush and nettle and the faithful man with the land covered with myrtle and cypress, just like the Garden of Eden.

\footnotetext{
14 "I know well that the language of the theologians often reflects something. Just like the ardent words of God need to be treated like roses, in the same way must the one without knowledge be touched with thorns in order to be on the side of God's vessels," Batthyány, 10.

${ }^{15}$ J. Parkinson, Theatrum botanicum (London, 1640), 118.

${ }^{16}$ R. Bradley, Dictionarium botanicum, vol. II (London, 1728), f.p.

${ }^{17}$ Batthyány, 10, footnote $\mathrm{n}$.
} 
Altogether, this would also be the meaning in Gerard's phrase, quoted above, which may be translated as: "I know well that the language of the theologians often reflects something. Just like the ardent words of God need to be treated like roses, in the same way must the one without knowledge be touched with thorns in order to be on the side of God's vessels." 